\title{
THERMOGRAVIMETRIC AND SPECTROSCOPIC STUDY (TG-DTA/FT-IR) OF ACTIVATED CARBON FROM THE RENEWABLE BIOMASS SOURCE BABASSU
}

\author{
Giulyane Felix de Oliveira a, Robson Carlos de Andrade ${ }^{\mathrm{b}}$, Magno Aparecido Gonçalves Trindade ${ }^{\mathrm{a}}$, Heloysa Martins Carvalho \\ Andrade $^{\mathrm{b}}$ and Cláudio Teodoro de Carvalho ${ }^{\mathrm{a}, *}$ \\ ${ }^{a}$ Universidade Federal da Grande Dourados, Rodovia Dourados-Itahum, km 12, 79804-970 Dourados - MS, Brasil \\ bUniversidade Federal da Bahia, Rua Professor Aristide Novis, 2, Federação, 40210-630 Salvador - BA, Brasil
}

Recebido em 23/08/2016; aceito em 01/11/2016; publicado na web em 25/11/2016

\begin{abstract}
Activated carbons (ACs) with well-developed microstructure and high microporosity were obtained from biomass by potassium hydroxide activation. The preparation process consisted in producing carbon materials in the ratios of activating agent to raw material 70:30, 50:50, 30:70 and 25:75 (w/w) characterized by thermal analysis coupled to spectroscopy (TG-DTA / FT-IR), scanning electron microscopy (SEM), $\mathrm{N}_{2}$ adsorption isotherms at $-196{ }^{\circ} \mathrm{C}$ and activation isotherm at 500 and $600{ }^{\circ} \mathrm{C}$ for $3.0 \mathrm{~h}$. Specific surface areas (SBET) within 728 and $1712 \mathrm{~m}^{2} \mathrm{~g}^{-1}$ and $\left(\mathrm{S}_{\text {mic }}\right)$ within 1054 and $1923 \mathrm{~m}^{2} \mathrm{~g}^{-1}$ were obtained, while the micropores surface area was calculated using the Dubinin-Astakhov (DA) equation and the pore size distribution calculated from density functional theory (DFT) was found to be in the range $1.09-1.77 \mathrm{~nm}$. Adsorption isotherms were fitted using Langmuir and Freundlich non-linear models and the adsorption capacity determined for methylene blue dye was between 27.13 and $459.20 \mathrm{mg} \mathrm{g}^{-1}$.
\end{abstract}

Keywords: babassu; adsorbent; thermal analysis; spectroscopy.

\section{INTRODUCTION}

Adsorbent materials like ACs have attracted growing interest in the late years due to their wide range of applications described in the literature, specially their use in liquids and gases purification, medicine, filtration, support material for catalysts, removal of metal ions and other applications. ${ }^{1-6}$ Such adsorbents may be derived from various sources like minerals and lignocellulosic material, even though the AC production from minerals presents some important disadvantages like high cost, low yields in carbonization and high ash content. ${ }^{7-10}$ Alternatively, lignocellulosic materials from agro-industrial and agricultural wastes such as peels, seeds or bagasse offer great potential to be used as raw carbon precursors due to their high carbon content and already proven high adsorption capacity. ${ }^{11-16}$

Babassu is a palm tree which belongs to the family Palmae, species Orbignya phalerata. This palm tree attains up to 20 meters in height and is native from South America, occurring widely in the north and north-east regions of Brazil, found in a transitional biome between the Amazon rainforest and the Caatinga ecosystems called Coconut Forests (Mata dos Cocais) and also along Bolivia, Colombia and Suriname. ${ }^{17-19}$

The main product obtained from Babassu is the kernel oil which is extracted by pressing the kernel, used like raw material in cosmetic industries, oleochemicals, biofuels and food. Around $7 \%$ of the fruit total weight is kernel, so the Babassu kernel oil yield is low. ${ }^{20,21}$

The Babassu palm petiole from its leaves is an attractive raw material for activated carbon production since it is a renewable and highly sustainable material not to mention its easy obtention and at a low cost which can not only add economic value to it but help in income generation and environment preservation.

In this regard, the main objective of this work is the production of activated carbon from Babassu petiole as raw material employing chemical activation method with potassium hydroxide $(\mathrm{KOH})$ as activating agent for obtention of a material with high superficial area and development of a highly microporous structure.

\footnotetext{
*e-mail: claudiocarvalho@ufgd.edu.br
}

\section{EXPERIMENTAL}

\section{Preparation of activated carbons from Babassu biomass}

The raw material, Babassu palm petiole, was provided by a private property from the north of the state of Mato Grosso do Sul - Brazil and initially ground using a knife grinder (Marconi-MA 340-A) and sieved to control the particles size at $2.00 \mathrm{~mm}$.

The samples of about 10 grams of the milled material were impregnated with the activating agent potassium hydroxide $(98 \%$ purity Merck) in the percentage ratios 70:30, 50:50, 30:70, 25:75 (m:m) of raw material/activating agent and dried at about $100{ }^{\circ} \mathrm{C}$ for at least 24 hours. The impregnated material was activated using a tubular furnace (reactor), inserted into a muffle furnace under a flow of nitrogen gas $\left(100 \mathrm{~mL} \mathrm{~min}{ }^{-1}\right)$ with activation process occurring at 500 and $600{ }^{\circ} \mathrm{C}$ for 3 hours. After activation, the remaining residue of activating agent was removed with distilled water in successive washes until neutral $\mathrm{pH}$. Then, the materials were dried in an oven at the temperature of $110{ }^{\circ} \mathrm{C}$ for 24 hours and stored in dessicator. The adsorbents produced have been generically abbreviated to AC, but from now on they will be identified with abbreviations according to their raw material/activating agent ratios, as follows: activated carbons at $500^{\circ} \mathrm{C} 70: 30(\mathrm{AC} 1), 50: 50$ (AC2), 30:70 (AC3), 25:75 (AC4) and at $600{ }^{\circ} \mathrm{C} 70: 30$ (AC5), 50:50 (AC6), 30:70 (AC7) and 25:75 (AC8).

\section{Immediate and thermal analyses}

The moisture, volatiles and biomass ashes contents from Babassu were determined according to the methods provided by the American Society for Testing and Materials (ASTM), namely ASTM E1756-08, ASTM D5832-98 and ASTM E1755-01.

Simultaneous TG-DTA curves were obtained by using the thermal analysis equipment TA Instruments model SDT 2960, with weight sensitivity of $0.1 \mu \mathrm{g}$ using air or $\mathrm{N}_{2}(99 \%$ pure) as purge gas with flow rate of $100 \mathrm{~mL} \mathrm{~min}^{-1}$. Heating rates of $20^{\circ} \mathrm{C} \mathrm{min}{ }^{-1}$ (ar) and $10{ }^{\circ} \mathrm{C}\left(\mathrm{N}_{2}\right)$ were adopted using alumina crucibles between 30 and $1000{ }^{\circ} \mathrm{C}$ for the samples with masses around $5.0 \mathrm{mg}$. 


\section{Evolved gas analysis}

The measurements of the gaseous products were carried out using a Thermogravimetric Analyzer Mettler TG-DSC coupled to a Nicolet FT-IR spectrophotometer with gas cell and DTGS $\mathrm{KBr}$ detector. The furnace and the heated gas cell $\left(250^{\circ} \mathrm{C}\right)$ were coupled through a heated $\left(\mathrm{T}=200{ }^{\circ} \mathrm{C}\right) 120 \mathrm{~cm}$ stainless steel line transfer of $2 \mathrm{~mm}$ in diameter both purged with dry air $\left(50 \mathrm{~mL} \mathrm{~min}^{-1}\right)$. The FT-IR spectra were recorded with 32 scans per spectrum at $4 \mathrm{~cm}^{-1}$ resolution.

\section{FT-IR analysis}

The main surface groups were identified by infrared spectroscopy using a FT-IR instrument (DigilabExcalibur-FT3000) and recorded within the range of $4000-400 \mathrm{~cm}^{-1}$, with a $4 \mathrm{~cm}^{-1}$ resolution and 16 scans. The samples of activated carbon powder were mixed on an agate mortar in a ratio of $\mathrm{KBr} /$ activated carbon of about 1:100 and ground on the agate mortar.

\section{Scanning electron microscopy analysis}

The chemical composition of the materials was evaluated using a Shimadzu EDX-720 energy-dispersive X-ray spectrometer. The morphology of the materials was studied using a scanning electron microscope (SEM), model Jeol JSM-6610LV, with accelerating voltage of $10.0 \mathrm{kV}$ and focus distance between 9 and $10 \mathrm{~mm}$. The magnification range used during the analysis ranged from $300 \mathrm{x}$ to 3000x. Before the analysis, the samples were fixed with tape carbon and coated with gold by a metallization process to obtain good surface conductivity.

\section{Textural analysis}

The textural properties of carbons were analyzed by nitrogen adsorption at $-196^{\circ} \mathrm{C}$ using the Micromeritics ASAP 2020 Physisorption Analyzer, at a relative pressure range of $10^{-7}$ to $0.99 \mathrm{P} / \mathrm{P}_{0}$. Before analysis, all samples were degassed at $300{ }^{\circ} \mathrm{C}$ for $10 \mathrm{~h}$ at $0.5 \mu \mathrm{m} \mathrm{Hg}$ vacuum. The specific surface area was measured by BET (BrunauerEmmett-Teller) method using the adsorption data at the relative pressure range of 0.05 to 0.3 . The surface area of the micropores was calculated using the Dubinin-Astakhov (DA) equation. The pore size distributions (PSD) were calculated using Density Functional Theory (DFT), employing the software supplied by Micromeritics and slit pores (slit-shaped) model to calculate the different pore sizes.

\section{Adsorption isotherms}

Adsorption tests for the ACs with methylene blue purchased from Sigma-Aldrich were performed by placing the samples in a shaker/ incubator under stirring for 24 hours at $30^{\circ} \mathrm{C}$. After this process, the solutions were filtered and the aliquots were analyzed using a Varian Cary ${ }^{\circledR} 50$ UV-Vis spectrometer, at the wavelength of $664 \mathrm{~nm}$. The methylene blue (MB) dye concentration was calculated considering the calibration curve previously obtained with experiments made in triplicate. The average amount of $\mathrm{MB}$ adsorbed on the AC samples corresponds to $Q e q\left(\mathrm{mg} \mathrm{g}^{-1}\right)$ and the concentration of free $\mathrm{MB}$ in the solution represented by $C e q\left(\mathrm{mg} \mathrm{L}^{-1}\right)$. The experimental isotherms were plotted $Q e q$ (y-axis) versus $C e q$ (x-axis).

Study of the isotherms was carried out employing the non-linear fitting method using the Origin 8.0 software (OriginLab Corporation, USA) in accordance with the Langmuir and Freundlich adsorption isotherm equations $Q e q=\frac{a b C e q}{(1+b C e q)}, Q e q=K C e q^{(1 / n)}$, respectively, in which $a$ and $b$ are the Langmuir constants and $k$ and $n$ are the Freundlich ones.

\section{RESULTS AND DISCUSSION}

\section{Immediate analysis and TG-DTA of the raw material}

From immediate analysis of the biomass it was identified low values of ash and volatile material contents and as a consequence a high fixed carbon content, with moisture of $0.36 \% \pm 0.004$, volatiles $23.11 \% \pm 0.009$ ash content $6.0 \% \pm 0.005$, and fixed carbon $76.53 \%$.

A low ash content and a high carbon content indicate that the biomass is a suitable raw material for activated carbon production, so that it is possible to infer that the Babassu biomass is adequate for activated carbon production.

The raw material Babassu was previously analyzed by thermal analysis (TGA-DTA) in nitrogen inert atmosphere before the ACs production being carried out in order to obtain information on the proper temperature range for the drying process, as well as on the region where there would be formation of carbonaceous material.

The thermal analysis of the raw material, Figure 1, using initial mass of $5 \mathrm{mg}$, basically occurs with mass loss of $10 \%$ between 30 and $90{ }^{\circ} \mathrm{C}$ attributed to adsorbed water, since the raw material had been previously dried at about $100{ }^{\circ} \mathrm{C}$ for at least 24 hours. The other mass loss steps with $64 \%$, starting at around $200{ }^{\circ} \mathrm{C}$, were attributed to the thermal degradation of hemicellulose and cellulose, forming a carbonaceous residue from $450{ }^{\circ} \mathrm{C}$ which decomposes slowly up to $1000{ }^{\circ} \mathrm{C}$. The final residue formed was of $25 \%$, which is consistent with a mixture of ash and carbon.

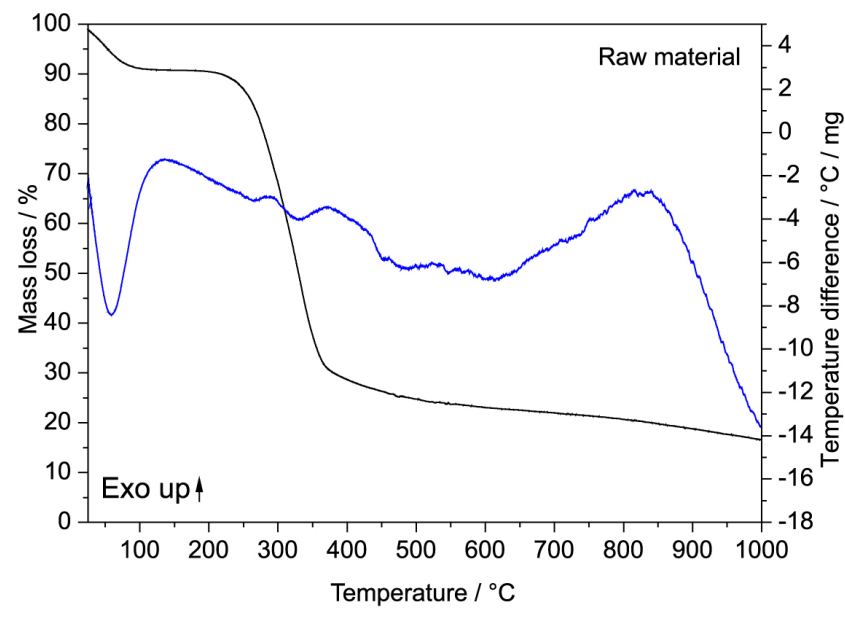

Figure 1. TGA-DTA curves in $\mathrm{N}_{2}$ atmosphere for the raw material

\section{TG-DTA of the activated carbons}

For the AC samples, TGA-DTA thermal analysis obtained in oxidizing atmosphere of dry air was used to study the thermal stability of the materials after the activation process in order to provide information on the adsorbed water and ash contents from the ACs produced with different activating agent ratios.

The ACs were obtained through two different activation temperatures, 500 and $600{ }^{\circ} \mathrm{C}$, in the raw material/activating agent percentage ratios 70:30, 50:50, 30:70 and 25:75\%. The thermal analysis of these materials, Figure 2, shows basically three mass loss steps (TG) with corresponding thermal events in the DTA curves. The first steps up to $100{ }^{\circ} \mathrm{C}$ show mass losses for the ACs between 5 and $12 \%$ due to the physically adsorbed water on the material, probably occurred during storage. Furthermore, the hygroscopicity in ACs samples can 
be related to the presence of oxygenated surface groups, responsible for hydrogen bonds between the water and the oxygen molecules, a suitable characteristic for adsorption of polar molecules. ${ }^{22}$

The decomposition product of the second and third mass loss steps can be assigned to the surface groups formed during the activation process, as well as to the carbon skeleton decomposition. In order to get further insight into the surface groups, a literature review has been done on papers reporting the degradation temperature of these groups employing different techniques. Taking such studies into consideration, it is possible to affirm that for the present study, in the second step groups such as carboxylic acids, carboxylic anhydrides and lactones, which are less thermally stable, decompose
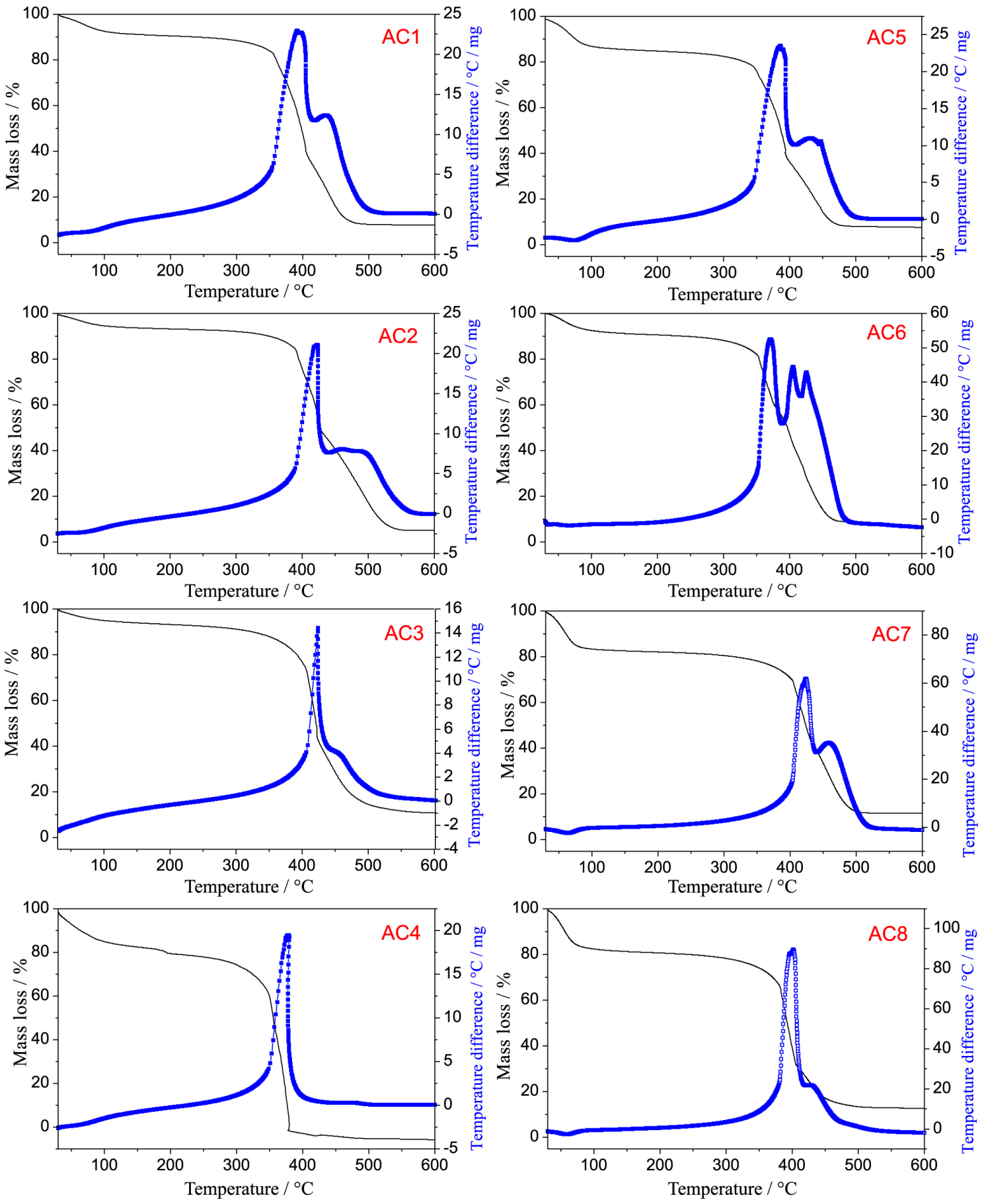

Figure 2.TGA-DTA curves in airatmospherefortheactivated carbonsprepared withfouractivating agentratios attwo differenttemperatures, 500 ${ }^{\circ} \mathrm{C}\left(\right.$ AC1-AC4) and $600^{\circ} \mathrm{C}$ $(A C 5-A C 8)$ 
Table 1. Energy-dispersive X-ray spectrometry (EDX) data for the majority of oxides found in the activated carbons obtained at $500{ }^{\circ} \mathrm{C}(\mathrm{AC} 1-\mathrm{AC} 4)$ and $600{ }^{\circ} \mathrm{C}$ (AC5-AC8)

\begin{tabular}{|c|c|c|c|c|c|c|c|c|c|}
\hline & $\% \mathrm{CaO}$ & $\% \mathrm{SiO}_{2}$ & $\% \mathrm{~K}_{2} \mathrm{O}$ & $\% \mathrm{Fe}_{2} \mathrm{O}_{3}$ & $\% \mathrm{MnO}$ & $\% \mathrm{ZnO}$ & $\% \mathrm{CuO}$ & $\% \mathrm{SO}_{3}$ & Others \\
\hline Raw Material & 12.2 & 60.6 & 22.7 & 0.96 & 0.97 & 0.44 & 0.28 & 0.95 & 0.82 \\
\hline $\mathrm{AC} 1$ & 36.7 & 36.4 & 15.8 & 5.04 & 3.62 & 1.10 & 0.39 & 0.92 & 0.06 \\
\hline $\mathrm{AC} 2$ & 24.9 & 56.5 & 3.06 & 5.89 & 4.43 & 0.99 & 0.37 & 2.30 & 1.63 \\
\hline $\mathrm{AC} 3$ & 31.6 & 47.4 & 1.88 & 2.58 & 1.72 & 0.53 & 0.18 & 1.80 & 12.33 \\
\hline $\mathrm{AC} 4$ & 28.5 & 36.2 & 6.78 & 8.10 & 1.32 & 0.29 & 0.12 & 2.27 & 16.41 \\
\hline AC5 & 41.8 & 25.2 & 22.7 & 4.76 & 2.13 & 0.62 & 0.32 & 1.68 & 0.86 \\
\hline AC6 & 44.1 & 24.1 & 23.8 & 3.33 & 2.08 & 0.57 & 0.30 & 1.84 & - \\
\hline $\mathrm{AC7}$ & 31.2 & 42.9 & 6.21 & 2.62 & 1.75 & 0.46 & 0.18 & 1.43 & 13.3 \\
\hline AC8 & 28.0 & 46.3 & 2.04 & 5.90 & 1.66 & 0.34 & 0.18 & 3.82 & 11.74 \\
\hline
\end{tabular}

elements in form of its oxides are shown in Table 1. It is observed that the residue is composed primarily of calcium, silicon, aluminum, potassium, iron, manganese, zinc, copper, sulfur and trace of others elements. Thus, from the TG-DTA and EDX is possible to estimate that the ACs are composed of $80.6-87.6 \%$ by carbon and oxygen.

\section{Analysis of the surface groups by FT-IR and TG-DTA/FT-IR}

Results of FT-IR measurements made for the modified activated carbons are shown in Figure 3 ( $\mathrm{AC} 1-\mathrm{AC} 8$ ) and provide information about the functional groups formed on the material surface, which are very important for the evaluation of the adsorption properties.

Broad bands between 3670 and $2979 \mathrm{~cm}^{-1}$ in the spectrum may indicate the presence of surface groups such as phenol, carboxylic acids, carboxylic acid derivatives, as well as the presence of physically adsorbed water on the material surface. These bands are generated by $\mathrm{O}-\mathrm{H}$ stretching, but usually the signal of $\mathrm{O}-\mathrm{H}$ stretching bands of carboxylic acids is intense in a wide range of the spectrum. On the other hand, fortunately the bands related to the formation of dimers of carboxylic acid are not present because the axial deformation of the $\mathrm{O}-\mathrm{H}$ group in this arrangement produces a very broad and intense band in the region of $3300-2500 \mathrm{~cm}^{-1}$, overlapping the $\mathrm{C}-\mathrm{H}$ stretching bands. Hence, the characteristic bands of average intensity assigned to axial stretching of $\mathrm{C}-\mathrm{H}$ bond can be observed alone at 2962 and $2853 \mathrm{~cm}^{-1}$. In addition, a small band at $720 \mathrm{~cm}^{-1}$ inherent to asymmetric angular deformation in the plan of the $\mathrm{C}-\mathrm{H}_{2}$ bond may be observed in the amplified spectrum of the AC5 sample.

Another consistent result is the absence of coupling bands between 1800 and $1900 \mathrm{~cm}^{-1}(\mathrm{C}=\mathrm{O}$ and $\mathrm{C}-\mathrm{O}-\mathrm{C})$ assigned to symmetric and asymmetric stretchings for carboxylic acid derived from anhydrides, which normally appear shifted by $60 \mathrm{~cm}^{-1}$. For the ketone groups, the $\mathrm{C}=\mathrm{O}$ stretching frequencies vary according to the ring size and the number of conjugations, i.e. the greater the ring and the number of conjugations, the smaller the stretching frequency. Thus, it is assumed that $\mathrm{C}=\mathrm{O}$ stretching bands for ketone surface groups are overlapped between 1550 and $1680 \mathrm{~cm}^{-1}$ in the same region as carboxylic acids and lactones.

Lactones or cyclic esters also present some important features which may assist to identify the intensity of the absorption frequency, for instance, lactones with five and six membered rings which have double bond conjugated to a $\mathrm{C}=\mathrm{O}$ functional group present a decrease in their $\mathrm{C}=\mathrm{O}$ absorption frequency, but if the unsaturation is located in the alpha position at the-O- group, the absorption frequency will be greater. Thus, it is suggested that the band located at $1746 \mathrm{~cm}^{-1} \mathrm{can}$ be attributed to lactonic groups (five-membered ring) with unsaturation at the $\mathrm{C}=\mathrm{O}$ position, while the peak at $1715 \mathrm{~cm}^{-1}$ can be assigned to lactonic groups (six-membered ring) with unsaturation, also at the $\mathrm{C}=\mathrm{O}$ position. Besides, these lactonic groups stand out as being thermally stable due to the lower tension of their ring structure, even though some subtle differences in the regions 1760 and $1520 \mathrm{~cm}^{-1} \mathrm{can}$ be observed between the FT-IR spectra of the activated carbons at 500 and $600{ }^{\circ} \mathrm{C}$ so that no band at $1746 \mathrm{~cm}^{-1}$ is observed for the carbon produced at $600{ }^{\circ} \mathrm{C}$, suggesting the presence of only six-membered ring lactones in the activated carbons from $\mathrm{AC} 5$ to $\mathrm{AC} 8$. Furthermore, from the spectra, Figure 3 ( $\mathrm{AC} 1-\mathrm{AC} 8$ ), it is possible to suggest that the aldehyde functional group is not present on the material surface due to the absence of the Fermi doublet, which occurs in the spectral range of 2738 to $2820 \mathrm{~cm}^{-1}$. Finally, the broad band at around $1000-1300 \mathrm{~cm}^{-1}$ can be associated with the $\mathrm{C}-\mathrm{O}$ stretching of ethers, lactones and phenols. The data obtained from FT-IR analysis for the surface groups are concisely displayed in Table 2.

The Gram-Schmidt (GS) curve of AC samples is shown in Figure 4. In this curve, the entire spectral range of each individual spectrum is integrated and the signal generated is represented as

Table 2. Spectroscopic data for the main surface groups for the activated carbons obtained at $500{ }^{\circ} \mathrm{C}(\mathrm{AC} 1-\mathrm{AC} 4)$ and $600{ }^{\circ} \mathrm{C}(\mathrm{AC} 5$-AC8)

\begin{tabular}{lccc}
\hline Surface groups & Exp. $\left(\mathrm{cm}^{-1}\right)$ & Lit. $\left(\mathrm{cm}^{-1}\right)$ & Assignment $\left(\mathrm{cm}^{-1}\right)$ \\
\hline Carboxylic acid & 1630 & $2500-3300,1665-1760,1120-1200$ & $\mathrm{O}-\mathrm{H}$ \\
Hydroxyl & 3440 & $3200-3600$ & $\mathrm{O}-\mathrm{H}$ \\
Lactones & 1630 & $1675-1790,1160-1370$ & $\mathrm{C}=\mathrm{O}$ \\
Phenol & 3430 & $1000-1220,1160-1200,2500-3620$ & $\mathrm{O}-\mathrm{H}$ \\
Cyclic structure & $\sim 1516$ & $1585-1600$ & $\mathrm{C}=\mathrm{C}$ \\
Carbon-hydrogen & $2915,2846,720$ & $2700-3000$ & $\mathrm{C}-\mathrm{H}, \mathrm{C}-\mathrm{H}_{2}$ \\
Quinones & $\sim 1550$ & $1550-1680$ & $\mathrm{C}=\mathrm{O}$ \\
Ethers & $\sim 1200$ & $1000-1300$ & $\mathrm{C}-\mathrm{O}$ \\
\hline
\end{tabular}

$\mathrm{R}=$ carbon chain, Exp. $=$ experimental, Lit. $=$ literature, $\sim=$ at around. 

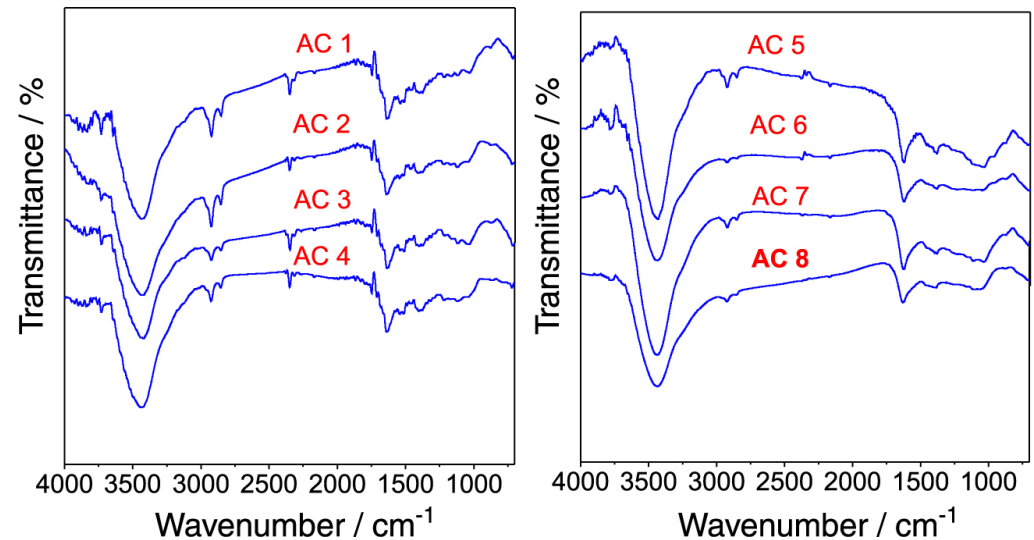

Figure 3. FT-IR spectra for the activated carbons prepared with four activating agent ratios at two different temperatures, $500{ }^{\circ} \mathrm{C}(\mathrm{ACl}-\mathrm{AC4})$ and $600{ }^{\circ} \mathrm{C}$ $(A C 5-A C 8)$

peaks, which are related to the quantitative measurement of the evolved gas composition in a determinate time or temperature range in the GS curve. Figure 4 show the GS curve of $\mathrm{AC} 1$ as representative of all activated carbon $(\mathrm{AC} 1-\mathrm{AC} 8)$ due to their similarity.

The gaseous products carbon monoxide $(\mathrm{CO})$ and carbon dioxide $\left(\mathrm{CO}_{2}\right)$ identified in the FT-IR spectra during the thermal decomposition (TG-DTA) of the ACs samples in $\mathrm{N}_{2}$ atmosphere for determinate temperature ranges observed in GS curve are due to surface groups. ${ }^{23}$ For the range $30-100{ }^{\circ} \mathrm{C}$, the FT-IR spectrum (a) shows bands located at around 3700 and $1500 \mathrm{~cm}^{-1}$ corresponding to adsorbed water, while between the ranges of $170-400$ and $530-580{ }^{\circ} \mathrm{C}$ the spectrum (b) shows $\mathrm{CO}_{2}$ as a thermal decomposition product of the carboxylic and lactonic groups respectively. ${ }^{24}$

For the ranges of $400-530$ and $580-600{ }^{\circ} \mathrm{C}$, the FT-IR spectrum (c) shows $\mathrm{CO}$ as the main product released. In the first range,
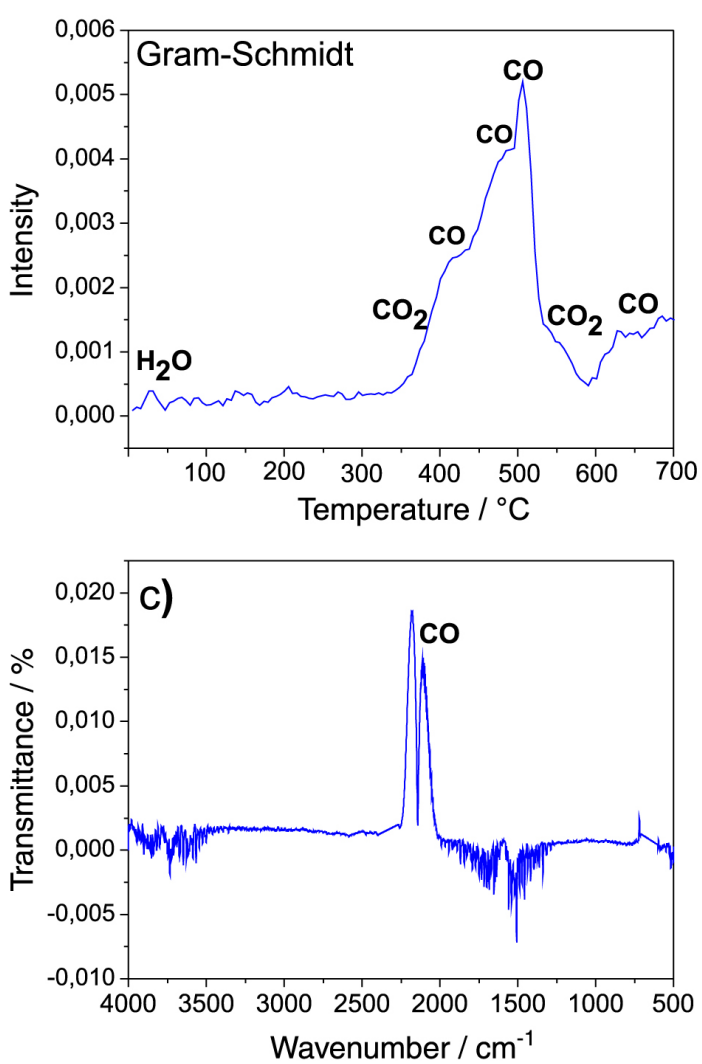

the three bands of high intensity are probably related to the thermal decomposition of the phenolic and lactone surface groups, whereas the second range is due to the quinone groups. Therefore, it is possible to affirm that according to these data, the activated carbons surface is mainly composed of phenolic and carbonyl groups, as well as of lactone and quinone groups and a small amount of carboxylic groups. Furthermore, there was no simultaneous release of $\mathrm{CO}$ and $\mathrm{CO}_{2}$, which confirms the absence of carboxylic anhydride groups on the material surface and corroborates the FT-IR data in solid state.

\section{Morphological analysis}

Morphological analysis carried out by SEM, Figure 5 (AC1 AC8), aimed to visualize the morphological characteristics obtained from the activation process with different raw material/activating
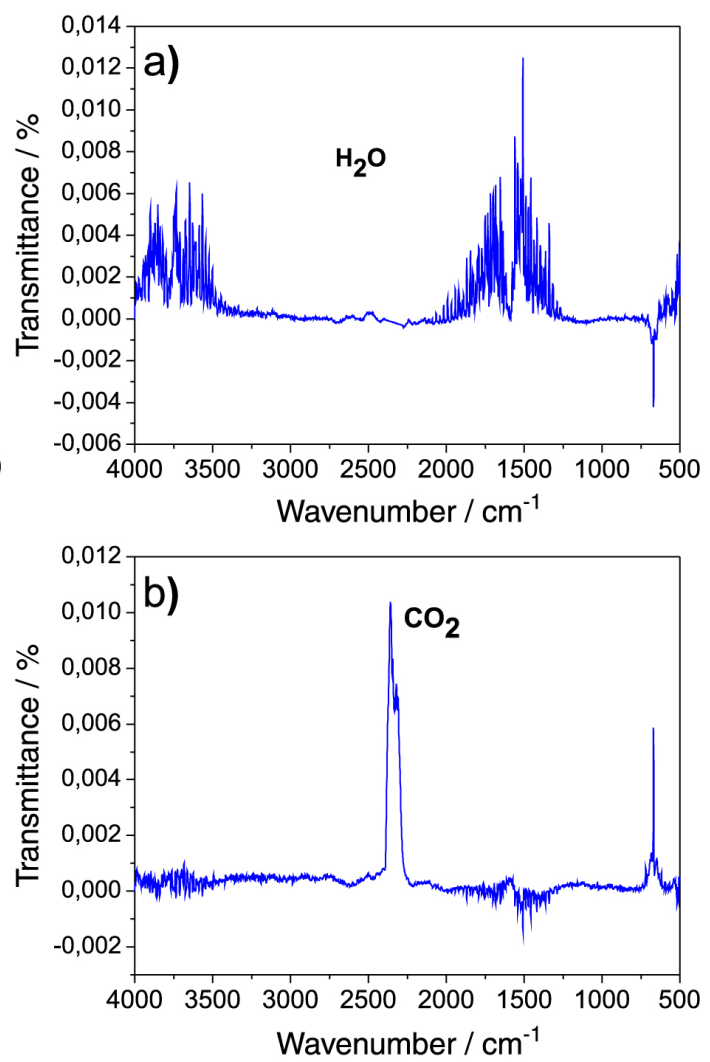

Figure 4. Identification of surface groups on the activated carbons from the monitoring of the gaseous products, $\mathrm{H}_{2} \mathrm{O}$ (a) $\mathrm{CO}_{2}\left(\right.$ (b) $\mathrm{CO}_{\text {(c) }}$, released at specific temperature ranges 

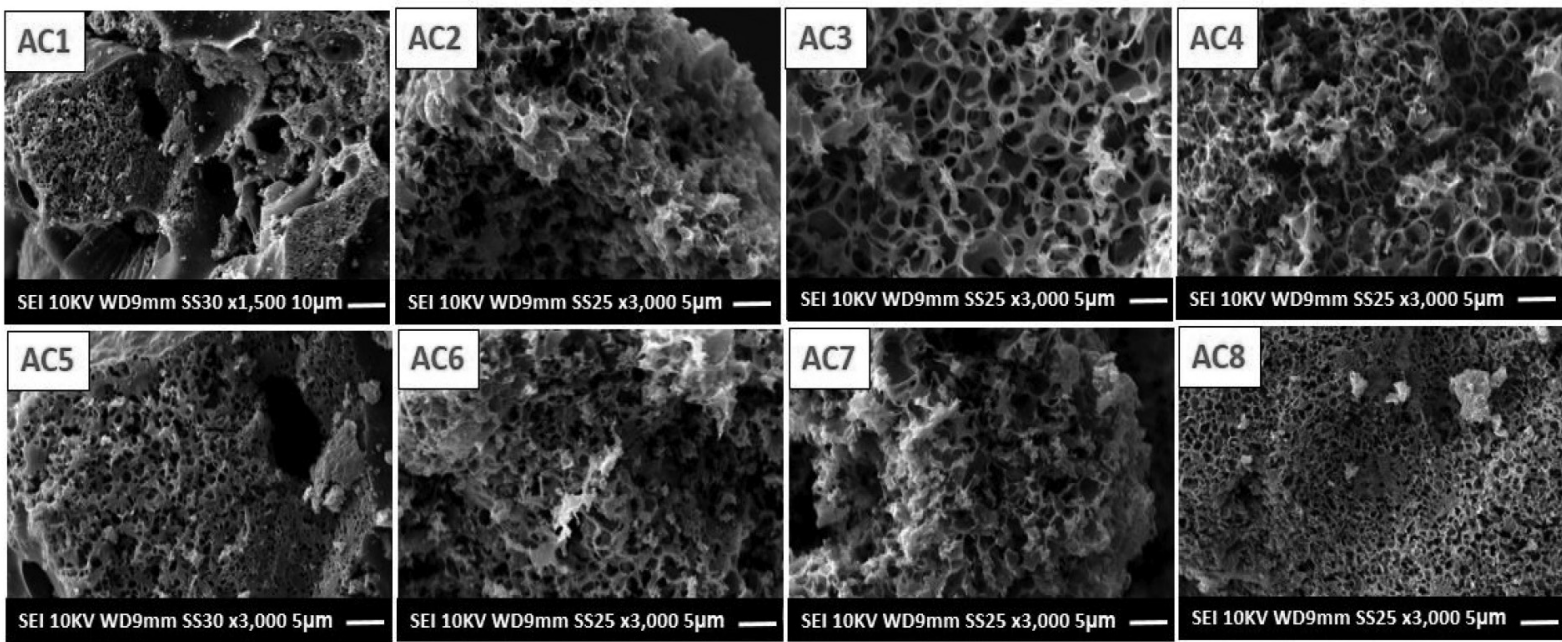

Figure 5. Micrographs obtained by SEM for the activated carbons prepared with four activating agent ratios at two different temperatures, $500{ }^{\circ} \mathrm{C}(\mathrm{AC} 1-\mathrm{AC4})$ and $600{ }^{\circ} \mathrm{C}(\mathrm{AC} 5-\mathrm{AC} 8)$

agent proportions, at the two temperatures of $500{ }^{\circ} \mathrm{C}(\mathrm{AC} 1-\mathrm{AC} 4)$ and $600{ }^{\circ} \mathrm{C}(\mathrm{AC} 5-\mathrm{AC} 8)$. In Figure 5 (AC1 - AC8), the micrographs show an outer surface quite rough and formed by irregular rings, which cannot be considered pores but connecting channels to the interior of the material, which is presumed to be permeated by different pore sizes. Furthermore, it is possible that the irregular rings observed especially in Figure 5 (AC3, AC4) evidence the cell walls of parenchyma and collenchyma tissues, common structures in young parts of plants, such as palm petioles. ${ }^{25}$

The pores represented by dark spots in the images, Figure 5, were formed through an aggressive heating process (burn-off), ${ }^{1,23}$ which along with the activating agent resulted in an apparent carbonaceous matrix with high porosity.

\section{Textural analysis}

In Figure 6 are shown the isotherms of adsorption and desorption of nitrogen of the carbons activated at 500 and $600{ }^{\circ} \mathrm{C}$. The carbons activated with potassium hydroxide at different ratios showed type I isotherms, according to the IUPAC classification, which is characteristic of microporous material. ${ }^{26}$

On the other hand, the isotherms of the activated carbons $\mathrm{AC} 1$, $\mathrm{AC} 2, \mathrm{AC} 5$ and AC6 can be classified as type IV, with hysteresis loop opening at nearly $\mathrm{P} / \mathrm{P}_{0}=0.4$, indicating small contribution of mesopores. ${ }^{26}$ However, the increase of the ratio and the temperature from 500 up to $600{ }^{\circ} \mathrm{C}$ led to a large increase in the BET area varying between 728 a $1712 \mathrm{~m}^{2} \mathrm{~g}^{-1}$ and to an increment of the area of micropores (DA) (1054 a $\left.1923 \mathrm{~m}^{2} \mathrm{~g}^{-1}\right)$, Table 3 .

The activation process using potassium hydroxide causes it to react strongly with the carbonaceous structures promoting the oxidation of the carbon to carbon dioxide and generating microporosity. ${ }^{27,28}$

The pores diameter distribution (PDD) for the activated carbons is concentrated in the micropores region, below $2 \mathrm{~nm}$, Figure 7(a-b). Furthermore, the slight variation in size of the micropores as shown in Table 3, can have been caused by the increase in potassium hydroxide / raw material ratio. ${ }^{27}$

\section{Adsorption isotherms}

The activated carbons produced from Babassu petiole were very efficient at removing methylene blue cationic dye from aqueous solutions over a large concentration range. Equilibrium data were fitted to the Langmuir and Freundlich non-linear isotherms and the Langmuir model was the best at describing these data according to the $R^{2}$ values obtained, as shown in Figure 8 and Table 4. This result shows that the ACs samples obtained present adsorption capacity for
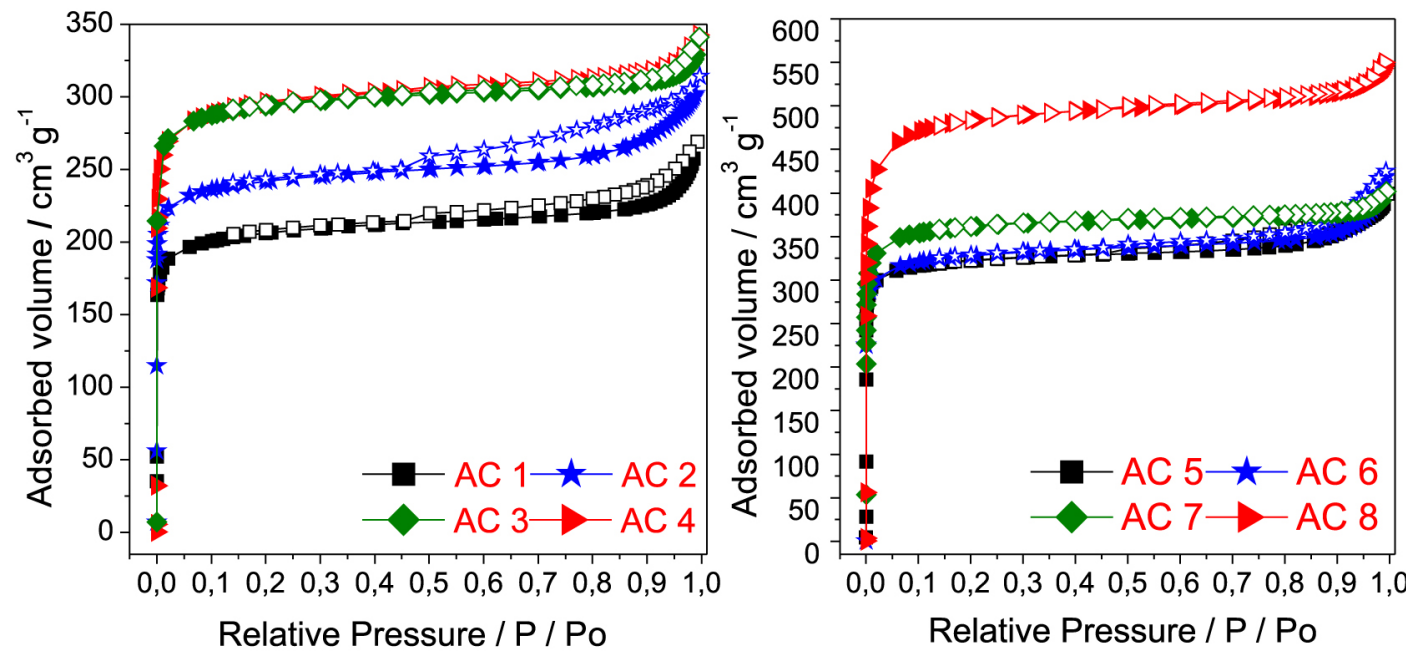

Figure 6. Nitrogen adsorption/desorption isotherms at $-196^{\circ} \mathrm{C}$ on activated carbons prepared with four activating agent ratios at two different temperatures, $500{ }^{\circ} \mathrm{C}(\mathrm{ACl}-\mathrm{AC} 4)$ and $600{ }^{\circ} \mathrm{C}(\mathrm{AC} 5-\mathrm{AC} 8)$ 
Table 3. Textural properties of the activated carbons obtained at $500{ }^{\circ} \mathrm{C}$ $(\mathrm{AC} 1-\mathrm{AC} 4)$ and $600{ }^{\circ} \mathrm{C}(\mathrm{AC} 5-\mathrm{AC} 8)$

\begin{tabular}{lcccc}
\hline Sample & $\mathrm{S}_{\mathrm{BET}}{ }^{\mathrm{a}} /\left(\mathrm{m}^{2} \mathrm{~g}^{-1}\right)$ & $\mathrm{S}_{\mathrm{mic}}^{\mathrm{b}} /\left(\mathrm{m}^{2} \mathrm{~g}^{-1}\right)$ & $\mathrm{Vt}^{\mathrm{c}} /\left(\mathrm{cm}^{3} \mathrm{~g}^{-1}\right)$ & $\mathrm{n}^{\mathrm{d}}$ \\
\hline $\mathrm{AC} 1$ & 728 & 1054 & 0.3983 & 1.30 \\
$\mathrm{AC} 2$ & 853 & 1250 & 0.4631 & 1.09 \\
$\mathrm{AC} 3$ & 1035 & 1301 & 0.5037 & 1.38 \\
$\mathrm{AC} 4$ & 1043 & 1341 & 0.5139 & 1.57 \\
AC5 & 1138 & 1478 & 0.5944 & 1.52 \\
AC6 & 1158 & 1469 & 0.6333 & 1.50 \\
AC7 & 1277 & 1515 & 0.6052 & 1.77 \\
AC8 & 1712 & 1923 & 0.8357 & 1.72 \\
\hline
\end{tabular}

${ }^{\mathrm{a}} \mathrm{S}_{\mathrm{BET}}$, surface area calculated by BET equation at $\mathrm{P} / \mathrm{P}_{0}=0.05-0.2$. ${ }^{\mathrm{b}} \mathrm{S}_{\text {mic }}$, surface area calculated by DA method. ${ }^{c} \mathrm{~V}_{\text {total }}$, total pore volume estimated from the adsorption amount at $\mathrm{P} / \mathrm{P}_{0}=0.98 .{ }^{\mathrm{d}}$ Exponent of the Dubinin-Astakhov equation.

dye removal at the range $27.13-459.20 \mathrm{mg} \mathrm{g}^{-1}$, which corroborates the evidence found that the increase in the activating agent ratios and in the total surface area as a consequence contributes to significant increase in the adsorption capacity. Furthermore, the treatment with $\mathrm{KOH}$ produces basic functional groups on the carbon surface, which enhances the adsorption of cationic dye.

Moreover, considering that the activated carbon samples have microporous carbon skeleton, close to $1 \mathrm{~nm}$, it is interesting to observe that depending on the surface area of the carbons obtained, the adsorption increased considerably despite the relatively large area of the MB molecule. Many discussions in this respect have been generated, and the agreed pore diameter for MB adsorption averages 1.3 $\mathrm{nm} .{ }^{29,30}$ Thus, it would be interesting that small deviations from the mathematical equations used could also be considered in the pore size determination.

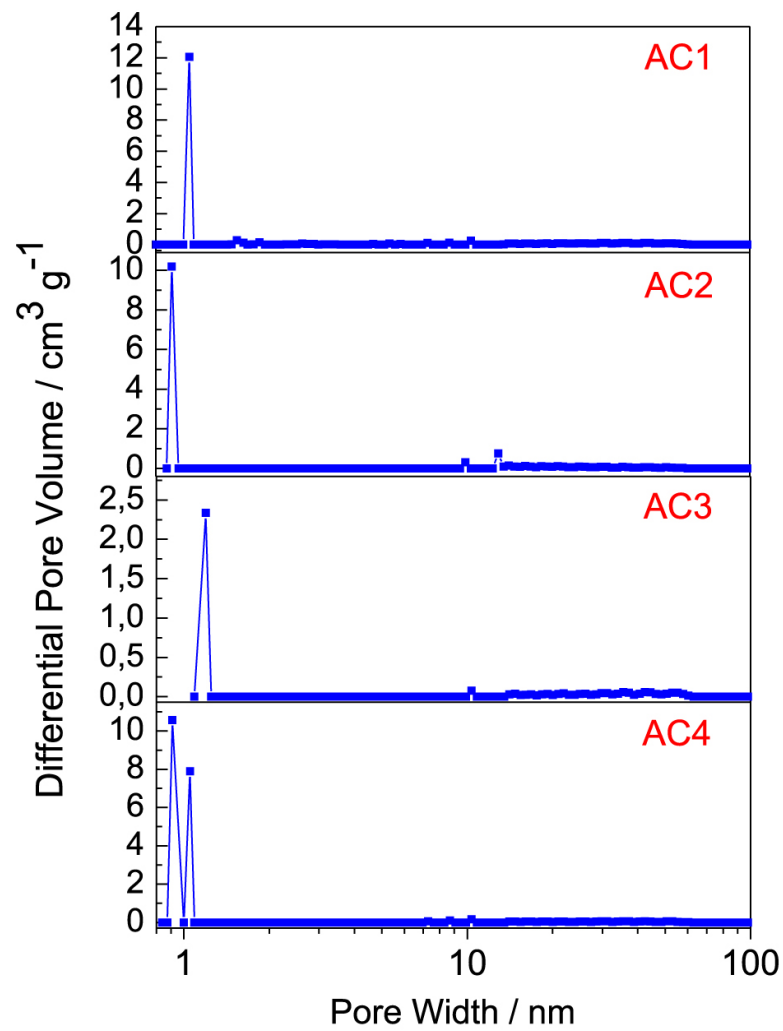

Regarding the isotherms, they present large increase in the adsorption capacity at low concentrations of MB dye, followed by a shift to a plateau form as this concentration gets higher. This profile best fits to the Langmuir model since the interaction between the adsorbate and adsorbent molecules occurs more strongly than that one among the adsorbate molecules, which is what the constant $b$ in Table 4 represents. For all ACs samples, the highest values of $b$ were obtained for the ACs at $600{ }^{\circ} \mathrm{C}(\mathrm{AC} 5-\mathrm{AC} 8)$.

\section{CONCLUSION}

Thermal analysis and coupled thermal analysis (TG-DTA and TG-DTA / FT-IR) have proven to be very useful in providing relevant information to be used in the optimization process of activated carbons production. Such information includes the proper temperature range for the drying process of the raw material, as well as the temperature range of formation of carbonaceous material. Furthermore, from TGDTA / FT-IR it was possible to suggest that the main surface groups present on the surface of the activated carbons are in accordance with the FT-IR spectroscopic data in solid state.

The textural and morphological analyses showed that the ACs were obtained with microporous matrix and large surface areas determined between 728 and $1712 \mathrm{~m}^{2} \mathrm{~g}^{-1}$. Despite being a microporous material, the adsorbent obtained can be assessed by adsorption tests with methylene blue dye in aqueous solution in order to evaluate its adsorption capacity. The Langmuir model adjusted better to the experimental results, suggesting that adsorption occurs mainly in monolayer by homogeneous sites.

From the characterization data, it was concluded that the porosity of the activated carbons obtained from Babassu raw material are highly dependent upon the temperature and the mass ratio of the activating agent potassium hydroxide.

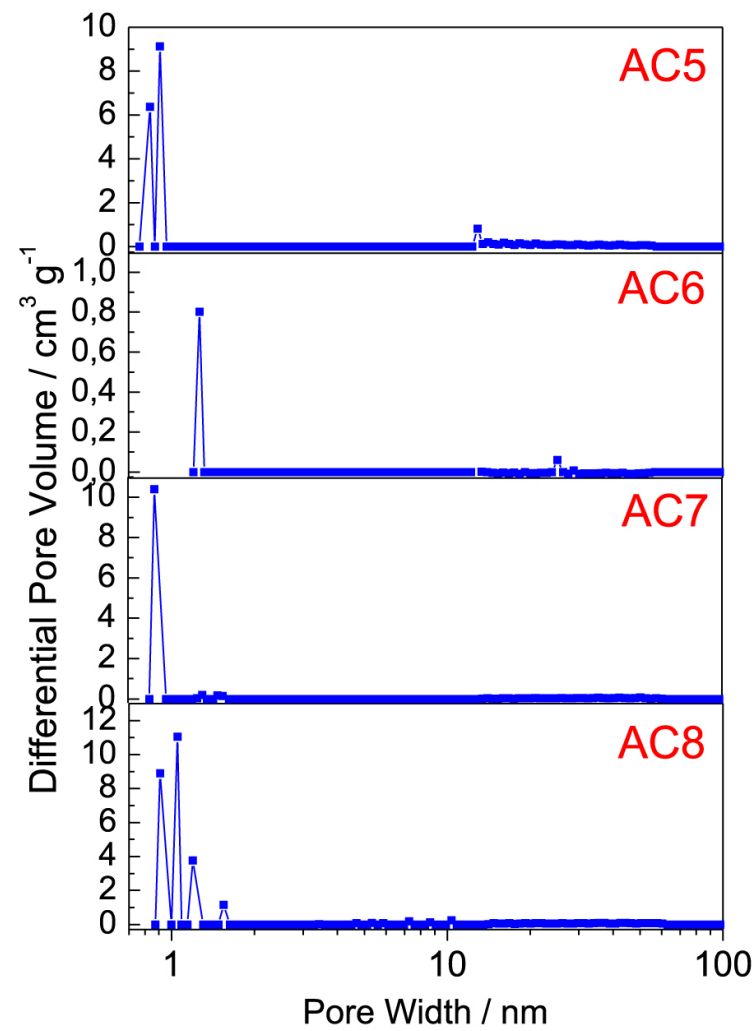

Figure 7. Pore size distribution for the activated carbons prepared with four activating agent rates at two different temperatures, $500{ }^{\circ} \mathrm{C}(\mathrm{AC} 1-\mathrm{AC} 4)$ and $600{ }^{\circ} \mathrm{C}$ (AC5 - AC8), calculated using the Density Functional Theory (DFT) 

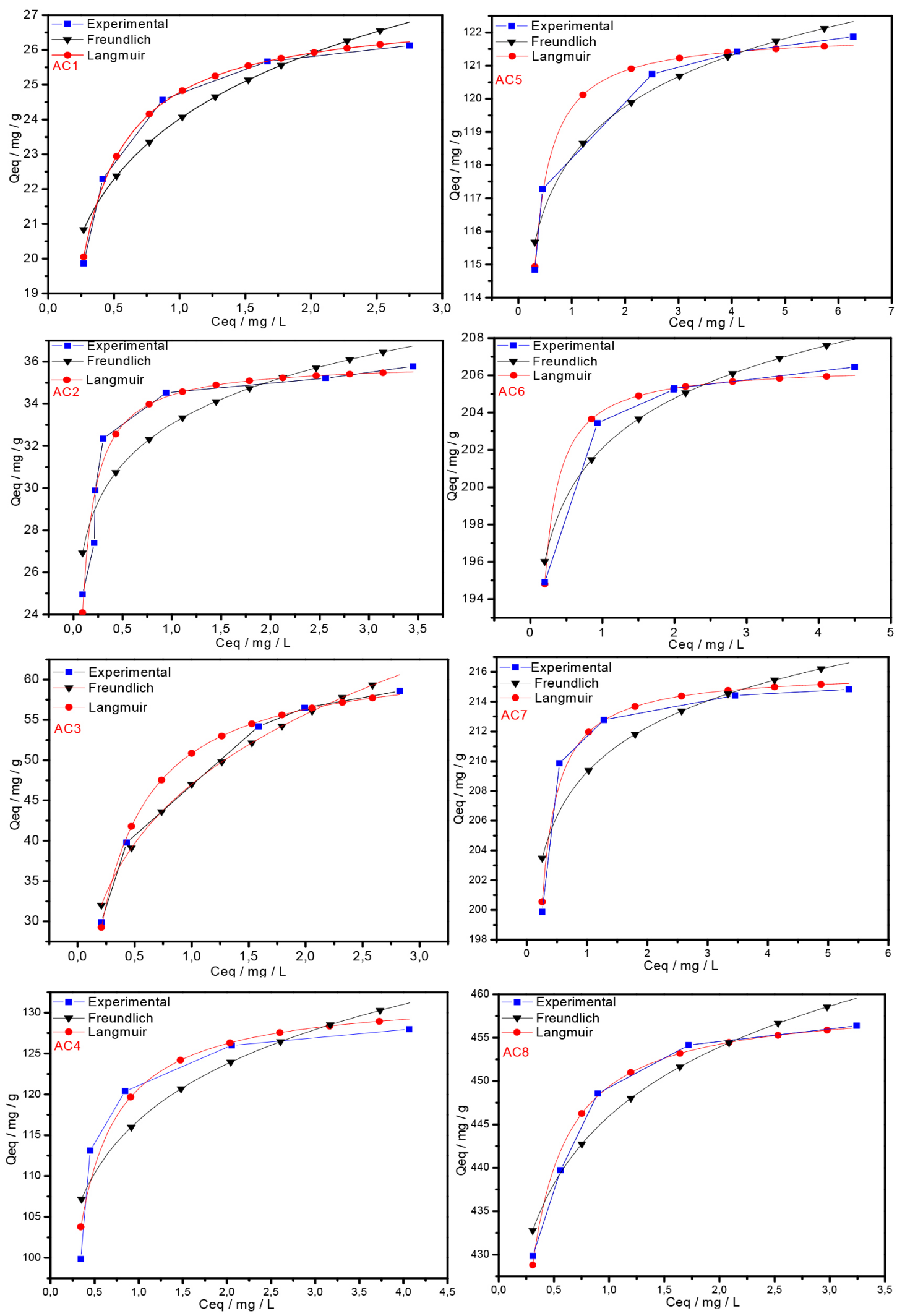

Figure 8. Isotherms at $30^{\circ} \mathrm{C}$ for blue methylene dye fitted to the Langmuir and Freundlich non-linear mathematical models, where Qeq is the dye mass adsorbed per gram of adsorbent and Ceq is the mass of the remaining dye in solution

\section{ACKNOWLEDGEMENTS}

The authors thank Ivo Giolito Thermal Analysis Laboratory (LATIG), Professor M. Ionashiro and Foundations Fundação de Apoio ao Desenvolvimento do Ensino, Ciência e Tecnologia do Estado de Mato Grosso do Sul (FUNDECT) Award Number 0146/12, Conselho Nacional de Desenvolvimento Científico e Tecnológico (CNPq) and CAPES Award Number 88887.103416/2015-01 for financial support. 
Table 4. Parameters from Langmuir and Freundlich mathematical models for blue methylene adsorption on the activated carbons at $500{ }^{\circ} \mathrm{C}(\mathrm{AC} 1-\mathrm{AC} 4)$ and $600{ }^{\circ} \mathrm{C}(\mathrm{AC} 5-\mathrm{AC} 8)$

\begin{tabular}{|c|c|c|c|c|c|c|c|}
\hline \multirow{2}{*}{$\mathrm{ACs}$} & \multirow{2}{*}{$\mathrm{S}_{\mathrm{BET}} /\left(\mathrm{m}^{2} \mathrm{~g}^{-1}\right)$} & \multicolumn{3}{|c|}{ Langmuir constants } & \multicolumn{3}{|c|}{ Freundlich constants } \\
\hline & & a & $\mathrm{b}$ & $\mathrm{R} 2$ & K & $1 / \mathrm{n}$ & $\mathrm{R} 2$ \\
\hline $\mathrm{AC} 1$ & 728 & 27.13 & 0.0105 & 0.995 & 24.018 & 0.108 & 0.878 \\
\hline $\mathrm{AC} 2$ & 853 & 35.96 & 0.0220 & 0.919 & 33.04 & 0.086 & 0.799 \\
\hline AC3 & 1035 & 63.08 & 0.0041 & 0.997 & 47.00 & 0.245 & 0.969 \\
\hline AC4 & 1043 & 132.30 & 0.0103 & 0.911 & 116.84 & 0.082 & 0.727 \\
\hline AC5 & 1139 & 121.90 & 0.0531 & 0.992 & 118.23 & 0.018 & 0.938 \\
\hline AC6 & 1159 & 206.5 & 0.0827 & 0.993 & 202.09 & 0.019 & 0.899 \\
\hline AC7 & 1278 & 216.02 & 0.0507 & 0.975 & 209.27 & 0.020 & 0.715 \\
\hline AC8 & 1712 & 459.20 & 0.0457 & 0.981 & 445.95 & 0.025 & 0.897 \\
\hline
\end{tabular}

$\mathrm{ACs}=$ activated carbon samples, $\mathrm{S}_{\mathrm{BET}}=$ surface area, $\mathrm{a}=$ Langmuir adsorption capacity $\left(\mathrm{mg} \mathrm{g}^{-1}\right), \mathrm{b}=$ Langmuir equilibrium constant $\left(\mathrm{Lg}^{-1}\right), \mathrm{K}=\mathrm{Freundlich}$ adsorption capacity $\left(\mathrm{mg} \mathrm{g}^{-1}\right), \mathrm{n}=$ affinity between adsorbent and adsorbate, $\mathrm{R} 2=$ correlation value.

\section{REFERENCES}

1. Ioannidou, O.; Zabaniotou, A.; Renewable Sustainable Energy Rev. 2007, 11, 1966.

2. Amicarelli, V.; Baldassarre, G.; Liberti, L.; J. Therm. Anal. Calorim. 1980, 18,155

3. Hameed, B. H.; Rahman, A. A.; J. Hazard. Mater. 2008, 160, 576.

4. Jain, A. K.; Gupta, V. K.; Bhatnagar, A.; Suhas; J. Hazard. Mater. 2003, 101,31 .

5. Amaya, A.; Píriz, J.; Tancredi, N.; Cordero, T.; J. Therm. Anal. Calorim. 2007, 89, 987.

6. Dinçer, A. R.; Güneş, Y., Karakaya, N. J.; J. Hazard. Mater. 2007, 141, 529.

7. Haimour, N. M.; Emeish, S.; Waste Manage. 2006, 26, 651.

8. Linares-Solano, A.; Martín-Gullon, I.; Salinas-Martínez de Lecea, C.; Serrano-Talavera B.; Fuel 2000, 79, 635.

9. Teng, H.; Yeh, T. S.; Hsu, L. Y.; Carbon 1998, 36, 1387.

10. Teng, H.; Hsu, L. Y.; Ind. Eng. Chem. Res. 1999, 38, 2947.

11. Patnukao, P.; Pavasant, P.; Bioresour. Technol. 2008, 99, 8540.

12. Al Bahri, M.; Calvo, L.; Gilarranz, M. A.; Rodriguez, J. J.; Chem. Eng. J. 2012, 203, 348 .

13. Kalderis, D.; Bethanis, S.; Paraskeva, P.; Diamadopoulos, E.; Bioresour. Technol. 2008, 99, 6809.

14. Xia, J.; Noda, K.; Kagawa, S.; Wakao, N.; J. Chem. Eng. Jpn. 1998, 31, 987.

15. Prapagdee, S.; Piyatiratitivorakul, S.; Petsom, A.; EnvironmentAsia 2014, 7, 60.
16. Dabrowski, A.; Podkościelny, P.; Hubicki, Z.; Barczak, M.; Chemosphere 2005, 58, 1049.

17. Teixeira, M. A.; Biomass Bioenergy 2008, 32, 857.

18. Almeida, R. R.; Lacerda, L. G.; Murakami, F. S.; Bannach, G.; Demiate, I. M.; Soccol, C. R.; Carvalho Filho, A. S.; Schnitzler, E.; Thermochim. Acta 2011, 519, 50.

19. Vinhal, J. O.; Lima, C. F.; Barbosa, L. C. A.; J. Anal. Appl. Pyrolysis 2014, 107, 73.

20. Teixeira, M. A.; Energy Convers. Manage. 2005, 46, 2068.

21. Maniglia, B. C.; Tapia-Blacido, D. R.; Food Hydrocolloids 2016, 55, 47.

22. Rodriguez-Reinoso, F.; Molina-Sabio, M.; Munecas, M. A.; J. Phys. Chem. 1992, 96, 2707.

23. Szymański, G. S.; Karpiński, Z.; Biniak, S.; Świaţkowski, A.; Carbon 2002, 40, 2627.

24. Figueiredo, J. L.; Pereira, M. F. R.; Freitas, M. M. A.; Órfão, J. J. M.; Carbon 1999, 37, 1379.

25. Pyykkö, M.; Ann. Bot. Fenn. 1985, 22, 129.

26. Sing, K. S. W.; Everett, D. H.; Haul, R. A. W.; Moscou, L.; Pierotti, R. A.; Rouquérol, J.; Siemieniewska, T.; Pure Appl. Chem. 1985, 57, 603.

27. Wu, F. C.; Tseng, R. L.; Juamg, R. S.; Sep. Purif. Technol. 2005, 47, 10.

28. Tseng, R. L.; Tseng, S. K.; Wu, F. C.; Hu, C. C.; Wang, C. C.; J. Chin. Inst. Chem. Eng. 2008, 39, 37.

29. Graham, D.; J. Phys. Chem. 1955, 59, 896.

30. Alaya, M. N.; Hourieh, M. A.; Youssef, A. M.; El-Sejariah, F.; Adsorpt. Sci. Technol. 2000, 18, 27. 